\title{
THE UTILIZATION OF CANNA STARCH (Canna edulis Ker.) AS AN ALTERNATIVE HYDROCOLLOID ON THE MANUFACTURING PROCESS OF YOGURT DRINK
}

\author{
Ahmad Khoirul Umam ${ }^{1,2)}$, Lilik Eka Radiati ${ }^{3)}$, Mei-Jen Lin ${ }^{4}$, and Shao-Yu Peng ${ }^{4)}$ \\ 1) Student of Master Post Graduate, Faculty of Animal Science, Brawijaya University, Veteran Street, Malang, \\ East Java, Indonesia. 65145 \\ 2) Student of Double Degree Department of Animal Science, National Pingtung University of Science and \\ Technology, Taiwan \\ 3) Faculty of Animal Science, Brawijaya University, Veteran Street, Malang, East Java, Indonesia. 65145 \\ 4) Department of Animal Science, National Pingtung University of Science and Technology, Taiwan \\ Ahmadkhoirulumam40@gmail.com
}

Diterima 15 Februari 2018; diterima pasca revisi 21 Maret 2018

Layak diterbitkan 28 Maret 2018

\begin{abstract}
Yogurt as a fermented dairy product has been providing several benefits for human health and appropriate for people with lactose intolerance. Recently, the consumption level of yogurt has significantly increased. Starch can be used as an alternative hydrocolloid in the manufacturing process of yogurt. Indonesian Canna edulis Ker contains $63.27 \%$ amylopectin that has the potential used as an alternative hydrocolloid. Amylopectin has a very high capability of the water holding capacity to increase the viscosity and maintain the stability of yogurt drink. The present research was to determine the additional effects of Canna starch as an alternative hydrocolloid on the physicochemical and sensory properties of the yogurt drink during storage. Concentrations of $0.1 \%$, $0.2 \%, 0.3 \%$, and $0.4 \%$ canna starch and 0.2\% CMC (control) were added to make yogurt. All treatments were carried out with four replications. Samples were refrigerated at $4^{\circ} \mathrm{C}$ for 24 hours and then analyzed for $\mathrm{pH}$, titratable acidity, viscosity, syneresis, sedimentable fraction, and sensory properties. Data were analyzed by one way ANOVA, and followed by Duncan's multiple range test (DMRT). Data from the $\mathrm{pH}$, titratable acidity, syneresis, sedimentable fraction, viscosity and sensory analyses obtained from the present study indicated that concentration of $0.1-0.4 \%(\mathrm{w} / \mathrm{v})$ Canna starch could be applicable in the manufacture of the yogurt drink. Furthermore, it was found that $0.1 \%(w / v)$ of Canna starch selected as the best concentration could be used in yogurt manufacture process that resulted in similar sensory quality compared with CMC as commercial hydrocolloid.
\end{abstract}

Keywords : Canna starch; hydrocolloid; yogurt drink

\section{ABSTRAK}

Yogurt merupakan produk susu fermentasi yang memiliki beberapa manfaat bagi kesehatan manusia serta sesuai untuk dikonsumsi bagi orang yang memiliki intoleran terhadap laktosa. Saat ini, konsumsi terhadap yogurt telah mengalami peningkatan secara signifikan. Pati ganyong (Canna edulis Ker) yang berasal dari Indonesia mengandung amilopektin sebanyak 63,27\% yang berpotensi untuk digunakan sebagai hidrokoloid alternatif. Amilopektin memiliki kemampuan mengikat air yang sangat baik untuk meningkatkan viskositas dan menjaga kestabilan minuman yogurt. Penelitian ini bertujuan untuk mengetahui efek penambahan pati ganyong sebagai hidrokoloid alternatif terhadap 
sifat fisik, kimia dan sifat sensoris minuman yogurt selama penyimpanan. Konsentrasi yang digunakan pada penelitian ini adalah 0,1\%, 0,2\%, 0,3\%, dan 0,4\% tepung ganyong dan 0,2\% CMC sebagai perlakuan kontrol. Semua uji coba dilakukan sebanyak empat kali ulangan. Sampel disimpan pada suhu $4^{\circ} \mathrm{C}$ selama 24 jam dan kemudian dilakukan analisis terhadap nilai pH, keasaman titrasi, viskositas, sineresis, fraksi sedimentasi, dan sifat sensorik. Pengolahan data percobaan menggunakan analisis ragam pola searah yang dilanjutkan dengan uji Duncan jika terdapat perbedaan. Data dari pH, keasaman titrasi, sineresis, fraksi sedimentasi, analisis viskositas dan sensoris yang diperoleh dari penelitian ini menunjukkan bahwa konsentrasi pati ganyong sebesar 0,1-0,4\% (b/v) dapat diaplikasikan pada pembuatan minuman yogurt. Konsentrasi pemberian pati ganyong sebanyak 0,1\% $(b / v)$ dipilih sebagai perlakuan terbaik yang menghasilkan kualitas sensorik serupa dengan minuman yogurt dengan penambahan CMC sebagai hidrokoloid komersial.

Kata kunci: Canna starch; hidrokoloid; yogurt drink

\section{INTRODUCTION}

Yogurt as a fermented dairy product has been providing several benefits for human health and appropriate for people with lactose intolerance (Wahyudi, 2006). Recently, the consumption level of yogurt has significantly increased (Granato et al., 2010). A various type of yogurt is already available in Indonesian market. Based on the texture, yogurt was divided into set yogurt and yogurt drink (Lee and Lucey, 2006). On the manufacturing process of yogurt, texture characteristic can be defined as quality parameters that affect the appearance, mouth-feel, and overall acceptability. Apparent viscosity variations, sedimentation of milk solids, and separation of whey were the most frequent problem related to yogurt texture that may lead to consumer rejection (Ares et al., 2007).

Hydrocolloids as thickening agents have been used to maintain the quality of yogurt product to provide an acceptably firm texture, increase the viscosity, and reduce syneresis(Saha and Bhattacharya, 2010; Tamime and Robinson, 2007). According to Gad and Mohamad (2014), the type of hydrocolloid was classified into gelatin that derived from animal, pectin derived from a

*Corresponding author:

Ahmad Khoirul Umam

Email : Ahmadkhoirulumam40@gmail.com

Faculty of Animal Science, Brawijaya University,

Veteran Street, Malang, East Java, Indonesia. 65145 plant extract and carboxymethyl cellulose (CMC) as synthetic hydrocolloids. Furthermore, starch can be used as alternative hydrocolloid in the manufacturing process of yogurt that has the capability to increase the viscosity (Ares et al., 2007).

Starch is a complex food hydrocolloid, polymer of $\alpha$-D-glucose and partially crystalline polymer. Starch granules absorb water resulting in swelling up to several times of their original size and losing their crystallinity. The complete process is known as gelatinization. Gelatinization of starch involves changes in amylase and amylopectin (Ahmed et al., 2008). Indonesian Canna starch contained $24.06 \%$ amylose and $63.27 \%$ amylopectin that has a very high capability of water holding capacity as to increase the viscosity and maintain the stability of yogurt (Carolina and Ilmi, 2016). Recently, Canna edulis Ker as local Indonesian food only processed into several products such as vermicelli noodles, cookies, crackers, and traditional product including cendol, porridge, and biscuits. Therefore, the objectives of this study were to investigate the effect of Canna starch (Canna edulis Ker) addition on the physicochemical and sensory properties of the yogurt drink.

How to cite:

Umam, A.K., Radiati, L.E., Lin, M.J., \& Peng, S.P.

(2018). The Utilization of Canna Starch (Canna edulis

Ker) As A Alternative Hydrocolloid on The

Manufacturing Process of Yogurt Drink. Jurnal Ilmu dan

Teknologi Hasil Ternak, 13 (1), 1-13 


\section{MATERIALS AND METHODS}

The research has been done at the Dairy Laboratory of Animal Science Department, National Pingtung University of Science and Technology, Taiwan. The materials were used in the manufacturing yogurt drink including raw cow milk, skim milk powder, Canna starch, Lactobacillus bulgaricus 12297, and Streptococcus thermophilus 14086.

\section{Canna starch preparation}

The preparation of Canna starch was modified from Awaluddin et al. (2017). Canna tubers was peeled, washed, cut into small pieces, mashed and mixed with some water. Canna with water was filtered about 7 times and then precipitated for $24 \mathrm{~h}$ to result whey and precipitate. Precipitate as starch was dried in oven $\left(48^{\circ} \mathrm{C}\right)$ for $24 \mathrm{~h}$. The dried starch was crushed and sieved with sieving number 80 to obtain powdered starch.

\section{Yogurt manufacturing}

Raw cow milk with $15 \%$ (w/v) skim milk powder addition was divided into 5 treatments, including $0.2 \%(\mathrm{w} / \mathrm{v}) \mathrm{CMC}$ (as the control group), $0.1 \% \quad(\mathrm{w} / \mathrm{v})$ Canna starch, $0.2 \%(\mathrm{w} / \mathrm{v})$ Canna starch, $0.3 \%$ (w/v) Canna starch, and $0.4 \%$ (w/v) Canna starch, respectively. After samples had been mixed thoroughly, then pasteurized at $85^{\circ} \mathrm{C}$ for $30 \mathrm{~min}$ and cooled to $43^{\circ} \mathrm{C}$. Samples were inoculated with $2 \%$ (v/v) of yogurt starter culture including $S$. thermophilus and $L$. bulgaricus, and mixed thoroughly. Samples were put into $200 \mathrm{~mL}$ sterilized bottle and incubated at $37^{\circ} \mathrm{C}$ for $22 \mathrm{~h}$ until $\mathrm{pH} 4.6$ was reached. After fermentation, yogurt samples were added with $10 \%(\mathrm{w} / \mathrm{v})$ sugar solution with ratio $1: 1$, then stored in $4^{\circ} \mathrm{C}$ refrigerator. Physicochemical and sensory properties were analyzed at the $1^{\text {st }}$ day of storage.

\section{Viscosity}

Dynamic viscosity was measured using the method modified from Kasinos et al. (2014). An amount of $80 \mathrm{~g}$ yogurt sample was inserted into a rotational viscometer (DV-II digital viscometer; Brookfield Engineering Laboratories, Inc., LR99102; Middleboro, MA, USA). All measurements were done at room temperature $\left(24^{\circ} \mathrm{C}\right)$ using a number 2 spindle set to $60 \mathrm{rpm}$.

\section{Syneresis}

Syneresis of each yogurt drink samples was measured using the modified method of Ares et al. (2007). An amount of $20 \mathrm{~g}$ yogurt sample was placed in a centrifuge tube and centrifuged $1200 \mathrm{rpm}$ at $4^{\circ} \mathrm{C}$ for 20 minutes (Hettich Centrifuger Universal 320R, Germany). The weight fraction of the supernatant recovered $(\% \mathrm{v} / \mathrm{w})$.

\section{Sedimentable fraction}

The sedimentable fraction determination is to measure the stability was using the method of Wuet al. (2013) an amount of $10 \mathrm{~g}$ yogurt sample was centrifuged at $4000 \mathrm{rpm}$ at $25^{\circ} \mathrm{C}$ for 20 minutes (Hettich Centrifuger Universal 320R, Germany). The sedimentable fraction value was counted by the ratio of the weight of sediment to the weight of the sample. All measurements were performed in triplicate.

\section{pH}

The $\mathrm{pH}$ of yogurt sample was measured using a Suntex $\mathrm{pH}$ Meter SP-2500 (Suntex Instruments Co., Ltd., New Taipei, Taiwan). The $\mathrm{pH}$ meter was calibrated with buffer standards of $\mathrm{pH} 4$ and $\mathrm{pH} 7$, rinsed thoroughly with distilled water before used on the sample. An amount of $50 \mathrm{~mL}$ yogurt sample was placed in beaker glass then inserted to $\mathrm{pH}$ meter in auto mode, and $\mathrm{pH}$ values were recorded in triplicate. 


\section{Titratable acidity}

Titratable acidity expressed as \% lactic acid in yogurt sample was measured according to Sabadoš (1996). An amount of $8.8 \mathrm{~g}$ yogurt sample mixed with $9 \mathrm{ml}$ of distilled water. Added $0.5 \mathrm{ml}$ phenolphthalein $(1 \%)$ and used $0.1 \mathrm{M}$ sodium hydroxide $(\mathrm{NaOH})$ to titrate.

\section{Sensory quality}

Sensory quality in this experiment used the method of Robinson and Itsaranuwat (2006), 15 semi-trained panelist consist of 8 Taiwanese female and 7 Taiwanese male were selected. All of the panelists already passed the triangle sensory test, then trained with the control sample $(0.2 \% \mathrm{CMC})$. The evaluation was scored on 5 point hedonic scale $(1=$ very different, $2=$ different, $3=$ moderate, $4=$ similar, $5=$ very similar). The score obtained according to appearance, flavor, taste, mouthfeel, and overall acceptability of all treatment groups compared with control sample.

\section{Statistical analysis}

Data obtained from the results of subsequent studies analyzed by one-way analysis of variance (ANOVA) and if there is any significant difference then continued by test using Duncan's Multiple Range Test (DMRT) at the $5 \%$ significance level $(\alpha=0.05)$ with SPSS for Windows version 16.

\section{RESULTS AND DISCUSSION}

The effect of Canna starch on $\mathrm{pH}$ and titratable acidity values of yogurt drink during fermentation process

Fermentation process on yogurt manufacture is a critical point that gives significantly affect the quality of final product. $\mathrm{pH}$ value and titratable acidity (TA) expressed as $\%$ of lactic acid were commonly used to determine the success of fermentation process. In this experiment, the fermentation process was stopped when yogurt reaches the $\mathrm{pH}$ 4.6. According to Chandan (2006), the standard $\mathrm{pH}$ value in commercial yogurt is about $4.5 \pm 0.1$ that has the function for resulted pleasant product appearance and preserve the shelf life and mild flavorAddition of Canna starch did not affect the initial $\mathrm{pH}$ and $\mathrm{TA}$, which ranged from 6.27 to 6.30 and from 0.36 to $0.40 \%$, respectively. However, during the fermentation process to reach 4.6 of $\mathrm{pH}$ value, higher percentage level of Canna starch addition showed in longer fermentation time of yogurt drink than CMC (Figure 1). The addition of CMC $0.2 \%(\mathrm{w} / \mathrm{v})$ resulted in the shortest fermentation time of yogurt drink with $22 \mathrm{~h}$, while $0.4 \%$ (w/v) addition of Canna starch resulted in the longest fermentation time about $28 \mathrm{~h}$. Fermentation time result of yogurt samples in this experiment was different with Shima et al. (2012) where yogurt added with sago starch oligosaccharides only need six hours of fermentation time to reach 4.6 $\mathrm{pH}$. This condition may be caused by several factors such as starter bacteria activity, incubation temperature, and fermentation time. 
A

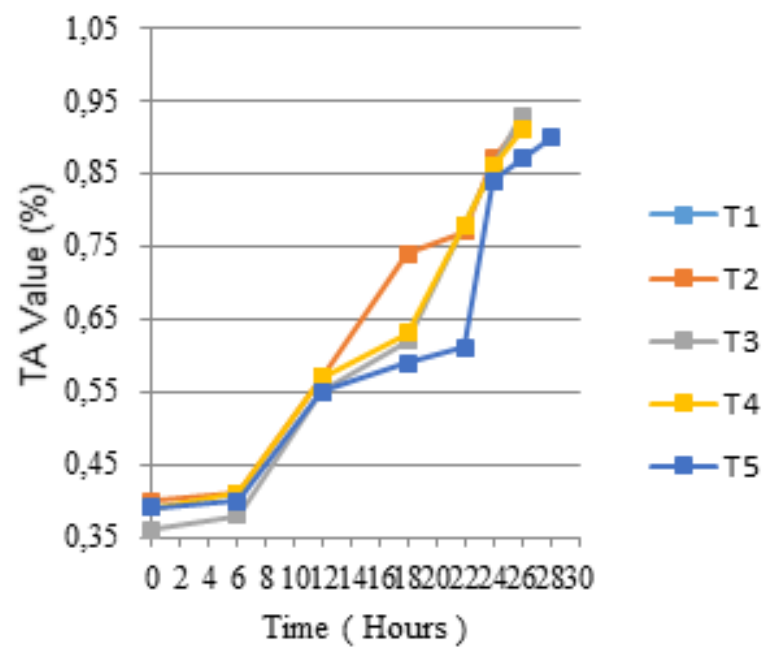

B

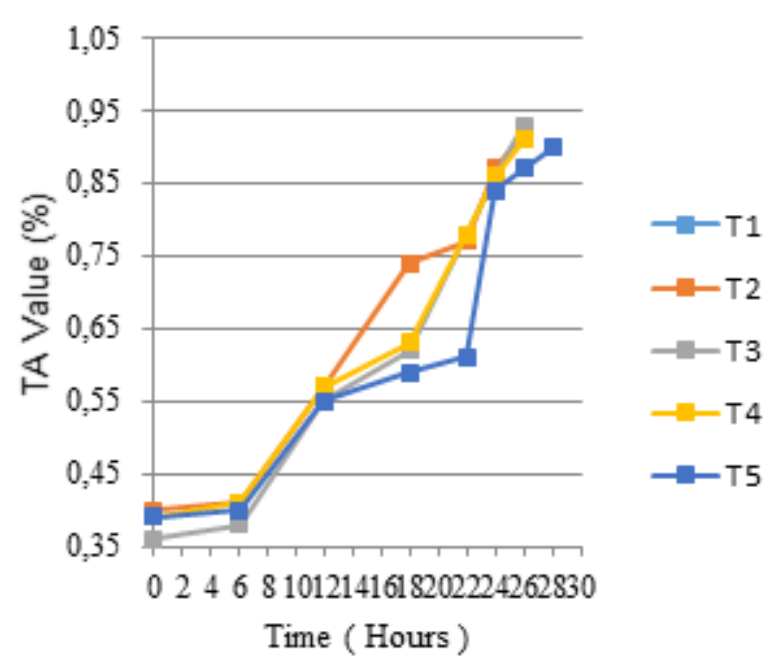

Remark: T1: 0.2\% CMC, T2: $0.1 \%$ Canna starch, T3: 0.2\% Canna starch, T4: $0.3 \%$ Canna starch, T5: 0.4\% Canna starch.

Figure 1. Changes in $\mathrm{pH}$ values (a) and TA values (b) of yogurts drink during fermentation process with different percentage of Canna starch compared to CMC.

This finding is in agreement with Tamime and Robinson (2007) in some cases, the addition of $3 \%(\mathrm{v} / \mathrm{v})$ active starter bacteria with the balance ratio of rods and cocci resulted incubation period less than $22 \mathrm{~h}$. While applying the low incubation temperature around $30^{\circ} \mathrm{C}$ was occurred longer incubation time (i.e., overnight) until the desired acidity is reached.Furthermore, The slower $\mathrm{pH}$ values reduction of yogurt drink in Canna starch addition than CMC addition suggested that some components present in Canna starch may have an inhibitory effect on the growth and metabolism of yogurt starter bacteria. According to Amirdivani and Baba (2011), the metabolic activity of lactic acid bacteria will affect the amount of organic acid produced that possible to reduce the $\mathrm{pH}$ value. The addition of plant extract to yogurt will affect the slower $\mathrm{pH}$ reduction that caused by the high phenolic compound that increases the buffering capacity (Michael et al., 2010). 
The addition of CMC $0.2 \%$ in yogurt drink (w/v) resulted in the highest titratable acidity values with $0.94 \%$ at the end of the fermentation process (Figure 1), while $0.4 \%$ (w/v) addition of Canna starch resulted in the lowest titratable acidity values with $0.90 \%$. The higher percentage of Canna starch addition produced lower titratable acidity value of yogurt drink. The phenolic compound present in Canna starch inhibited the growth of starter bacteria that affected the total amount of lactic acid bacteria in yogurt product. As shown by the results for $\mathrm{pH}$ and $\mathrm{TA}$ in this study, the addition of Canna starch may inhibit the metabolic activities of yogurt starter cultures, resulting in longer fermentation times than control samples.

\section{Physicochemical characteristic of yogurt drink on the $1^{\text {st }}$-day storage pH and TA value}

Changes in $\mathrm{pH}$ and $\mathrm{TA}$ values of yogurt drink during the $1^{\text {st }}$ day of storage was presented in Table 1. Yogurt drink with addition of CMC and Canna starch showed no significant differences ( $\mathrm{p}>0.05)$ in $\mathrm{pH}$ value over the $1^{\text {st }}$ day of storage. Titratable acidity (TA) values of the yogurt drink with the addition of $0.2 \% \mathrm{CMC}$ was significantly higher $(\mathrm{p}<0.05)$ than Canna starch addition on the $1^{\text {st }}$ day of storage. The addition of $0.2 \%$ CMC improved $0.94 \%$ of TA of yogurt drink, higher percentage level of Canna starch resulted in lower total acidity. Canna starch as hydrocolloid can be used as a stabilizer in yogurt product. The addition of stabilizer will inhibit the starter bacterial growth and metabolism that reduce the acid production and affected to the lower TA values of yogurt (Prasanna et al., 2014).

However, according to Gad and Mohamad (2014), the use of a synthetic stabilizer such as $\mathrm{CMC}$ in yogurt can keep the acidity and buffering capacity in constant value during storage. The decreased $\mathrm{pH}$ of yogurt during refrigerated storage is caused by some $L$. delbrueckii subsp bulgaricus and $S$. thermophilus as starter bacteria that still active to ferment lactose then produce small amounts of lactic acid (Shah et al., 1995). Several conditions can prolong the decrease of $\mathrm{pH}$ value during storage that has been mentioned by Dzigbordi et al. (2013) such as the level of total solids (TS) and total soluble solids (TSS), bacterial growth rate, present of probiotic or spoilage microorganisms, amount of additives added (e.g. fruits), and storage temperatures

\section{Syneresis rate}

Syneresis or wheying-off is the main problem in yogurt production that closely related to the shelf life. In order to determine the physiological quality of yogurt samples, syneresis rate was measured on the $1^{\text {st }}$ day of storage. The rate of syneresis in yogurts varied significantly $(\mathrm{p}<0.05)$ with the addition of Canna starch, the higher level of Canna starch added has resulted in lower syneresis than control. Syneresis values of yogurt drink during storage are presented in Table 1.

The mean of syneresis were

T1: $31.70 \pm 0.36 \%$,

$\mathrm{T} 2: 33.43 \pm 1.03 \%$,

T3: $31.97 \pm 0.51 \%$,

T4: $30.40 \pm 0.56 \%$, and

T5: $29.43 \pm 0.97 \%$, respectively.

According to Table 1, the mean of syneresis rate of yogurt added with $0.4 \%(\mathrm{w} / \mathrm{v})$ Canna starch (T4) was the lowest value of $29.43 \%$ and the addition of $0.1 \%(\mathrm{w} / \mathrm{v})$ Canna starch (T1) as the highest with value of $33.43 \%$. The addition of various percentages level Canna starch suppressed the syneresis of yogurt drink caused the amylopectin in canna starch could be able to binding water. 
Table 1. pH, titratable acidity, syneresis, viscosity, and sedimentable fraction results during $1^{\text {st }}$ storage day

\begin{tabular}{cccccc}
\hline Treatment & T1 & T2 & T3 & T4 & T5 \\
\hline pH & $4.60 \pm 0.01$ & $4.59 \pm 0.01$ & $4.61 \pm 0.01$ & $4.60 \pm 0.02$ & $4.61 \pm 0.01$ \\
\hline $\begin{array}{c}\text { Titratable } \\
\text { Acidity }(\%)\end{array}$ & $0.94 \pm 0.02^{\mathrm{a}}$ & $0.91 \pm 0.01^{\mathrm{b}}$ & $0.92 \pm 0.01^{\mathrm{ab}}$ & $0.91 \pm 0.01^{\mathrm{b}}$ & $0.90 \pm 0.01^{\mathrm{b}}$ \\
\hline $\begin{array}{c}\text { Syneresis (\%) } \\
\text { Viscosity (cP) }\end{array}$ & $31.70 \pm 0.36^{\mathrm{bc}}$ & $33.43 \pm 1.03^{\mathrm{d}}$ & $31.97 \pm 0.51^{\mathrm{c}}$ & $30.40 \pm 0.56^{\mathrm{ab}}$ & $29.43 \pm 0.97^{\mathrm{a}}$ \\
\hline $\begin{array}{c}\text { Sedimentable } \\
\text { fraction (\%) }\end{array}$ & $0.71 \pm 0.02^{\mathrm{c}}$ & $0.68 \pm 0.01^{\mathrm{bc}}$ & $0.66 \pm 0.02^{\mathrm{ab}}$ & $0.66 \pm 0.01^{\mathrm{ab}}$ & $0.64 \pm 0.03^{\mathrm{a}}$ \\
\hline $\begin{array}{c}\text { Remarks :T1: } 0.2 \% \mathrm{CMC}, \mathrm{T} 2: 0.1 \% \text { Canna starch, T3: 0.2\% Canna starch, T4: } 0.3 \% \text { Canna starch, T5: 0.4\% Canna starch. } \\
\text { Samples were stored at } 4{ }^{\circ} \mathrm{C}\end{array}$ & $80.1 \pm 0.65^{\mathrm{a}}$ & $98.9 \pm 0.38^{\mathrm{b}}$ & $121.3 \pm 1.53^{\mathrm{c}}$ & $152.8 \pm 2.02^{\mathrm{d}}$ \\
\hline
\end{tabular}

The result of this experiment is similar to Kiros et al. (2016) where syneresis rate significantly decreased with the increase of added stabilizer in yogurt fortified with carrot juice. Increasing the concentration levels addition of hydrocolloid material to yogurt was significantly reduce the occurring of syneresis that caused by high water holding capacity (Radi et al., 2009).

According to Kala $b$ et al. (1983), different steps can be taken to reduce syneresis as to increase the total solids by adding more protein or add thickening starch and gelatin. Yogurt drink manufactured with gelatin has proven to reduce the whey separation, it is indicated that gelatin as negatively charged hydrocolloid gives rejection on the positively-charged protein molecules in yogurt that could stabilize the matrix (Gaonkar, 1995).

In addition, Canna starch gel properties have an opportunity to bind the protein as well as water binding capability for decrease syneresis. Hematyar et al. (2012) stated that protein gel is an essential point in the yogurt manufacturer because the intrinsic gel instability will lead water loss (syneresis) during storage time.

The protein hydrophilic was increased when stabilizer added that affect syneresis reduction. Hydrogen bonds between water molecules and proteins weakened, and pores between the casein molecules loosened so that it can be passed by the free water (Nawangwulan et al., 2015).

\section{Sedimentable fraction}

The quantity of sedimentable fraction was used to determine the stability of milk proteins under acidic conditions. Sedimentable fraction significantly $(p<0.05)$ decreased with the increase of added stabilizer, the higher level of Canna starch added has resulted in lower sedimentable fraction than control on the $1^{\text {st }}$ day of storage. The percentage of the sedimentable fraction of yogurt drink is shown in Table 1. The mean of sedimentable fraction were $\mathrm{T} 1$ $0.71 \pm 0.02 \%$, T2 $0.68 \pm 0.01 \%$, T3 $0.66 \pm 0.02 \%$, T4 $0.66 \pm 0.01 \%$, and T5 $0.64 \pm 0.03 \%$, respectively. Table 1 showed the mean of sedimentable fraction of yogurt drink added with $0.2 \%$ (w/v) CMC (T1) was the highest value $0.71 \%$ and the addition of $0.4 \%(\mathrm{w} / \mathrm{v})$ Canna starch (T5) as the lowest with value $0.64 \%$.

Canna starch reduced the sedimentable fraction of yogurt drink that caused by amylopectin capability to prevent the casein aggregates sedimentation. Some theories have explained by Tuinier et al. (2002) the specific mechanism stabilization when acidified milk systems reach 5.0 of $\mathrm{pH}$; pectin adsorption has done via electrostatic interactions. The interaction between pectin and casein has resulted two regions network, the first as region high negative charge had strongly bind the 
casein particles surface. The second region describe as dangling tails and loops was protruded on the surface of lower charge region that closely linked to steric repulsion between the casein aggregates (Kiani et al., 2010).

Furthermore, Tromp et al. (2004) explained the function of weak gel network in pectin was averting casein aggregates sedimentation that affected long-term stability. Weak gel assumed to have the capability to prevent the colliding of casein particles and was formed in the serum phase. Thus, the type and concentration of pectin added, $\mathrm{pH}$ level, and ionic strength was influenced the stability of acidified milk drink.

On the other hand, the addition of $0.2 \%$ (w/v) CMC was not enough to reduce the sedimentable fraction of yogurt drink; it was caused by level CMC added was not enough to cover on the whole of protein particles and aggregation of protein particles that referred to bridging flocculation. This result was similar to Wuet al. (2014) yogurt drink added with $0.1 \%$ and $0.2 \%(\mathrm{w} / \mathrm{v})$ of CMC resulted in unstable product although $\mathrm{CMC}$ was adsorbed onto the protein particles. However, increasing CMC concentration about $0.4 \%$ to $0.6 \%$ (w/v) could decrease the amount of CMC absorbed, this condition could occur in yogurt drink may be the improving interaction between $\mathrm{CMC}$ with denatured whey proteins.

According to $\mathrm{Du}$ et al. (2007), the interaction between casein micelles and CMC at low $\mathrm{pH}$ has a similar process as casein micelles stabilized by k-caseins in neutral $\mathrm{pH}$. Moreover, excess CMC that did not absorb by protein was beneficial for the colloidal systems stability, inhibit the sedimentation rate and improve the viscosity of acidified milk drink.

\section{Viscosity}

Viscosity is the primary factor in the prevention of settling and the aggregation of solids suspended in drinks. Viscosity values indicated a significant difference $(p<0.05)$ between the yogurt drink with the addition of
CMC and Canna starch. The addition of $0.4 \%$ (w/v) Canna starch resulted in the thickest yogurt with $152.8 \mathrm{cP}$ of viscosity, the higher percentage level of Canna starch resulted in thicker in yogurt texture. The similar result was showed between $0.2 \% \mathrm{CMC}$ with $78.3 \mathrm{cP}$ and $0.1 \%$ Canna starch with $80.1 \mathrm{cP}$, respectively.

The addition of Canna starch increased the viscosity due to fairly high pectin content that has a good capability to form the interactions system with protein molecules in yogurt drink. This is in agreement with Damian et al. (2017) several utilities of using starch such as waterbind capability, high molecular weight, and forming of the casein-starch system capability has improved the yogurt rheological properties. According Setianto et al. (2014) pectin was useful in the formation of gel in yogurt drink when the acidic condition was reached and could use as a stabilizer. Starch is a solid source contained amylopectin which has a significant water absorption thus increasing the viscosity (Ares et al., 2007).

According to Shihata and Shah (2002), the increasing viscosity of the yogurt drink is caused by the addition of dissolved solids such as starch. However, longer storage time will affect to lower viscosity due to post acidification activity of bacterial starter still produce proteolytic enzymes. In addition,Nilsson et al. (2006) explained that viscosity measurements can also be used to determine the optimal use of pectin concentrations when the viscosity of yogurt increased during storage.

Gad and Mohamad (2014) have proved that high methoxyl pectin (HMP) was improved the stability of drinkable nonfat yogurt. When in the low value of $\mathrm{pH}$, high methoxyl pectin molecules were in negatively charged then interact with casein micelles as positively charged to form a stable complex. Covalent linkage between protein and polysaccharide represents an attractive interaction. This mechanism was affecting the viscosity value 
that may affect the mouthfeel and other sensory characteristics.

Khalifa and Ibrahim (2015) the increasing of modified starch added in camel's milk yogurt has increased the viscosity, the change was related to the firm gel resulted from the interaction between modified starch and casein particles. Heat treatment and milk composition, casein concentration, starter bacteria characteristic and incubation temperature were several factors that influence gel structure and viscosity (Iličić et al., 2013).

\section{Similarity sensory testing of yogurt added with Canna starch}

The using of additive ingredients might change the quality of final product. Meanwhile, there is no recent information about the effect of Canna starch on the sensory quality of yogurt product. The application of Canna starch as an alternative hydrocolloid in yogurt is expected to result in similar quality if compared with the commercial hydrocolloid. Similarity testing is required to determine the equivalence or similarity between control (CMC) and treatments (Canna starch). The yogurt samples were tested a day after manufacturing. The radar diagram of the seven sensory attributes for different Canna starch percentage compared with the control sample $(0.2 \% \mathrm{CMC})$ is shown in Figure 2. The higher score of color, acidic, sourness, sweetness, smoothness, thickness, and overall acceptability were indicated the more similar to the control.

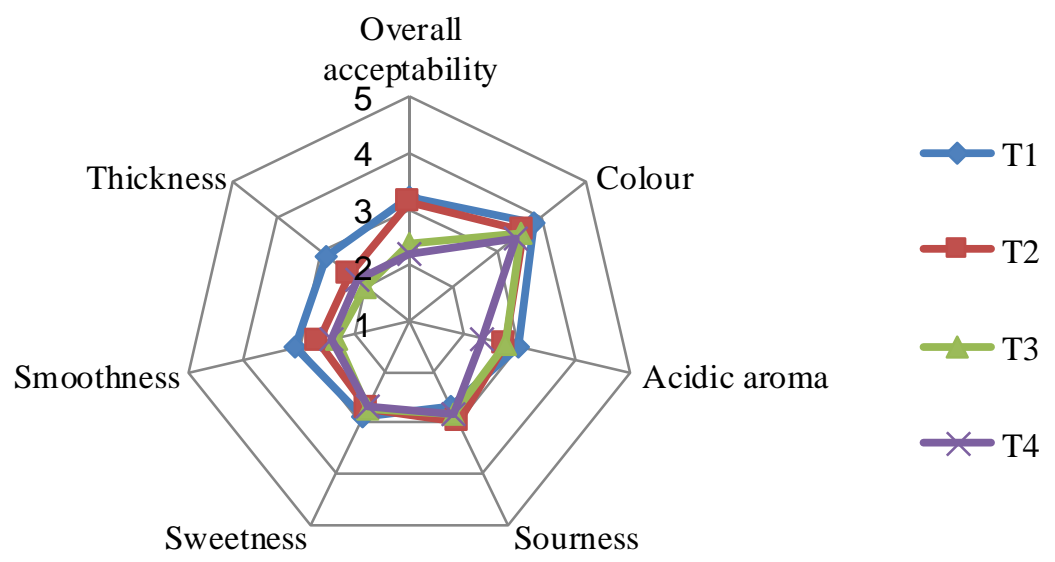

Remarks : T1: $0.1 \%$ Canna starch, T2: 0.2\% Canna starch, T3: $0.3 \%$ Canna starch, T4: 0.4\% Canna starch.Samples were stored at $4^{\circ} \mathrm{C} ; 1$ - very different to 5-very similar.

Figure 2 Radar diagram of yogurt sensory properties for different Canna starch percentage compared with control sample $(0.2 \% \mathrm{CMC})$ during $1^{\text {st }}$ storage day.

The most similar color (3.80 point) compared with the control was showed in yogurt added with $0.1 \%$ (w/v) Canna starch ( $>0.05)$. Nevertheless, the level of similarity was decreased when the greatest concentration $(0.4 \%, w / v)$ of Canna starch was added into yogurt drink, probably because of the original light white color of Canna starch.

The addition of $0.1 \%(\mathrm{w} / \mathrm{v})$ Canna starch showed the moderately similar level of smoothness (3.07 point) to control $(\mathrm{p}>0.05)$, lower smoothness is correlated to the larger particle size. The moderately similar (3.00 point) of acidic aroma also found in $0.1 \%(\mathrm{w} / \mathrm{v})$ Canna starch group treatments $(\mathrm{p}>0.05)$. However, the sourness of yogurt drink added with $0.2 \%(\mathrm{w} / \mathrm{v})$ showed the most similar $(3.00$ point) compared to the control ( $p>0.05)$. Sourness was related to the presence of various acid in the yogurt during fermentation Gad and Mohamad (2014). 
The addition of $0.1 \%(\mathrm{w} / \mathrm{v})$ Canna starch in yogurt drinks is shown a similarity (2.87 point) compared to the control based on sweetness profile $(p>0.05)$ and thickness $(p<0.05)$. Increasing the concentration of Canna starch has been shown to increase the thickness of yogurt drink. Finally, adding 0.1\% (w/v) Canna starch into the yogurt drink significantly $(\mathrm{p}<0.05)$ resulted in the similarity overall scores compared with control. Based on all the sensory data obtained from the current study, it is suggested that $0.1 \%(\mathrm{w} / \mathrm{v})$ of Canna starch is the best concentration could be used as an alternative hydrocolloid in yogurt manufacture without the deterioration of sensory properties.

\section{CONCLUSION}

The data of $\mathrm{pH}$, titratable acidity, syneresis, sedimentable fraction, viscosity and sensory analyses in this study indicated that a $0.1-0.4 \%(\mathrm{w} / \mathrm{v})$ concentration of Canna starch were applicable in the manufacture of the yogurt drink. Furthermore, it was found that $0.1 \%$ (w/v) Canna starch addition was the best concentration used in yogurt manufacture process that resulted in similar sensory quality to $\mathrm{CMC}$ addition as a commercial hydrocolloid.

\section{ACKNOWLEDGEMENT}

This research was supported by double degree program of Brawijaya University, Indonesia and National Pingtung University of Science and Technology, Taiwan. We also would like to thank all the members of Dairy Laboratory of Animal Science Department for their help to finish this experiment

\section{REFERENCES}

Ahmed, J., Ramaswamy, H. S., Ayad, A., \& Alli, I. (2008). Thermal \& dynamic rheology of insoluble starch from basmati rice. Food Hydrocolloids, 22(2), 278-287. https://doi.org/10.1016/j.foodhyd.2006.11.014

Amirdivani, S., \& Baba, A. S. (2011). Changes in yogurt fermentation characteristics, and antioxidant potential \& in vitro inhibition of angiotensin-1 converting enzyme upon the inclusion of peppermint, dill and basil. LWT - Food Science and Technology, 44(6), 1458-1464. https://doi.org/10.1016/j.1wt.2011.01.019

Ares, G., Gonçalvez, D., PÉrez, C., Reolón, G., Segura, N., Lema, P., \& Gámbaro, A. (2007). Influence of gelatin \& starch on the instrumental and sensory texture of stirred yogurt. International Journal of Dairy Technology, 60(4), 263-269. https://doi.org/10.1111/j.1471-0307.2007.00346.x

Awaluddin, R., Prasetya, A. W., Nugraha, Y., Suweleh, M. F., Kusuma, A. P., \&Indrati, O. (2017). Physical modification \& characterization of starch using pregelatinization \& co-process of various tubers from Yogyakarta as an excipient. In AIP Conference Proceedings (Vol.1823).https://doi.org/10.1063/1.4978184

Carolina, A., \& Ilmi, F. N. (2016). Production of Indonesian Canna edulis type IV resistant starch through acetylation modification. International Food Research Journal, 23(2), 491-497.

Chandan, R. (2006). Manufacturing of yogurt \& fermented milks. Ames, Lowa: Blackwell Publishing Professional.

Damian, C., Oroian, M.A., Leahu, A., \& Cioarbă, I. (2017). Effect of addition of starch \& agar-agar on rheological behaviour of yogurt. Food and Environment Safety Journal, 11(1), 97-102.

Du, B., Li, J., Zhang, H., Chen, P., Huang, L., \& Zhou, J. (2007). The stabilization mechanism of acidified milk drinks 
induced by carboxymethylcellulose. Lait, 87,287-300.https://doi.org/10.1051/lait:2007021

Dzigbordi, B., Adubofuor, J., \& Faustinadufie, W. M. (2013). The effects of different concentrations of natamycin \& the point of addition on some physicochemical \& microbial properties of vanilla-flavoured yoghurt under refrigerated condition. International Food Research Journal, 20(6), 3287-3292.

Gad, A. S., \& Mohamad, S. H. S. (2014). Effect of hydrocolloid type on physiochemical properties of nonfat drinkable yogurt fermented with ropy and non-ropy yogurt cultures. Comunicata Scientiae, 5(3), 318-325.

Gaonkar, A. (1995). Ingredient interactions. New York, USA: Marcel Dekker, Inc.

Granato, D., Branco, G. F., Cruz, A. G., Faria, J. de A. F., \& Shah, N. P. (2010). Probiotic dairy products as functional foods. Comprehensive Reviews in Food Science and Food Safety, 9(5), 455-470. https://doi.org/10.1111/j.1541-4337.2010.00120.x

Hematyar, N., Samarin, A. M., Poorazarang, H., \& Elhamirad, A. H. (2012). Effect of gums on yogurt characteristics. World Applied Sciences Journal, 20(5), 661665. https://doi.org/10.5829/idosi.wasj.2012.20.05.2353

Iličić, M. D., Milanović, S. D., Carić, M. D., Vukić, V. R., Kanurić, K. G., Ranogajec, M. I., \& Hrnjez, D. V. (2013). The effect of transglutaminase on rheology \& texture of fermented milk products. Journal of Texture Studies, 44(2), 160168. https://doi.org/10.1111/jtxs. 12008
Kalab, M., Wojtas, P. A., \& Todd, B. E. P. (1983). Development of microstructure in set-style nonfat yogurt -a review. Journal of Food Structure Food $M$ icrostructure, 2(2), 51-66.

Kasinos, M., Tran Le, T., \& Van der Meeren, P. (2014). Improved heat stability of recombined evaporated milk emulsions upon addition of phospholipid enriched dairy by-products. Food Hydrocolloids, 34 , 112-118. https://doi.org/10.1016/j.foodhyd.2012.11.030

Khalifa, S. A., \& Ibrahim, A. H. (2015). Influence of addition modified starches as stabilizer on physicochemical and textural properties of camel milk yoghurt. Zagazig J. Agric. Res., 42(2), 295-307.

Kiani, H., Mousavi, M. E., Razavi, H., \& Morris, E. R. (2010). Effect of gellan, alone $\&$ in combination with highmethoxy pectin, on the structure \& stability of doogh, a yogurt-based Iranian drink. Food Hydrocolloids, 24(8), 744-754. https://doi.org/10.1016/j.foodhyd.2010.03.016

Kiros, E., Seifu, E., Bultosa, G., \& Solomon, W. K. (2016). Effect of carrot juice \& stabilizer on the physicochemical \& microbiological properties of yoghurt. LWT - Food Science and Technology, 69, 191-196. https://doi.org/10.1016/j.1wt.2016.01.026

Lee, W.-J., \&Lucey, J. A. (2006). Impact of gelation conditions \& structural breakdown on the physical and sensory properties of stirred yogurts. Journal of Dairy Science, 89(7), 2374-2385. https://doi.org/10.3168/jds.S0022-0302(06)72310-4 
Michael, M., Phebus, R. K., \& Schmidt, K. A. (2010). Impact of a plant extract on the viability of Lactobacillus delbrueckii ssp. bulgaricus \& Streptococcus thermophilus in nonfat yogurt. International Dairy Journal, 20(10), 665-672. https://doi.org/10.1016/j.idairyj.2010.03.005

Nawangwulan, R., Utami, R., \&Nurhartadi, E. (2014). The effect of red sweet potato ( ipomoeabatatas 1.) Substitution on skim milk as prebiotic on synbiotic drink powder characteristic. In International Congress " Challenges of Biotechnological Research in Food \& Health.

Nilsson, L. E., Lyck, S., \&Tamime, A. Y. (2006). Production of drinking products. In Fermented Milks (pp. 95-126). Ayr, UK: Blackwell Publishing company.

Prasanna, P. H. P., Grandison, A. S., \&Charalampopoulos, D. (2014). Bifidobacteria in milk products: An overview of physiological \& biochemical properties, exopolysaccharide production, selection criteria of milk products \& health benefits. Food Research International, $\quad 55, \quad 247-262$. https://doi.org/10.1016/j.foodres.2013.11.013

Radi, M., Niakousari, M., \&Amiri, S. (2009). Physicochemical, textural \& sensory properties of low-fat yogurt produced by using modified wheat starch as a fat replacer. Journal of Applied Sciences. https://doi.org/10.3923/jas.2009.2194.2197

Robinson, R. K., \& Itsaranuwat, P. (2006). Properties of yoghurt \& their appraisal. In A. Tamimem (Ed.), Fermented Milks (pp. 76-92). Ayr, UK: Blackwell Publishing company.
Sabadoš, D. (1996). Control \& assessment of quality milk \& dairy products 2nd Edn. Zagreb. Croatian Dairy Union, 166-169.

Saha, D., \& Bhattacharya, S. (2010). Hydrocolloids as thickening \& gelling agents in food: A critical review. Journal of Food Science and Technology, 47(6), 587-597.https://doi.org/10.1007/s13197-010-0162-6

Setianto, Y. C., Pramono, Y. B., \& Mulyani, S. (2014). Nilai pH, viskositas , \& tekstur yoghurt drink dengan penambahan ekstrak salak pondoh ( salaccazalacca). JurnalAplikasiTeknologiPangan, 3(3), 110-113.

Shah, N. P., Lankaputhra, W. E. V, Britzb, M. L., \& Kyle, W. S. A. (1995). Survival of Lactobacillus acidophilus \& Bifidobacteviumbijidzm in Commercial Yoghurt During Refrigerated Storage. $\mathrm{Ht}$. Dairy Journal5, 5, 515-521. https://doi.org/10.1016/0958-6946(95)00028-2

Shihata, A., \& Shah, N. P. (2002). Influence of addition of proteolytic strains of Lactobacillus delbrueckii subsp. bulgaricus to commercial $\mathrm{ABT}$ starter cultures on texture of yoghurt, exopolysaccharide production \& survival of bacteria. International Dairy Journal, 12(9), $765-772$. https://doi.org/10.1016/S0958-6946(02)00071-7

Tamime, A. Y., \& Robinson, R. K. (2007). Yogurt science and technology. Abington Hall, Abington, Cambridge CB21 6AH, England: Woodhead Publishing Limited.

Tromp, R. H., De Kruif, C. G., Van Eijk, M., \& Rolin, C. (2004). On the mechanism of stabilisation of acidified milk drinks by pectin. Food Hydrocolloids, 18(4), 565572.

https://doi.org/10.1016/j.foodhyd.2003.09.005 
Tuinier, R., Rolin, C., \& de Kruif, C. G. (2002). Electrosorption of pectin onto casein micelles. Biomacromolecules, 3(3), 632638. https://doi.org/10.1021/bm025530x

Wahyudi, M. (2006). Proses pembuatan \& analisis mutu yoghurt. Buletin Teknik Pertanian, 11(12), 12-16.
Wu, J., Du, B., Li, J., \& Zhang, H. (2014). Influence of homogenisation \& the degradation of stabilizer on the stability of acidified milk drinks stabilized by carboxymethylcellulose. LWT - Food Science and Technology, 56(2), 370-376. https://doi.org/10.1016/j.lwt.2013.12.029

Wu, J., Liu, J., Dai, Q., \& Zhang, H. (2013). The stabilisation of acidified whole milk drinks by carboxymethylcellulose. International Dairy Journal, 28(1), 4042. https://doi.org/10.1016/j.idairyj.2012.05.005 